\title{
Quantitative Study of the Metaphorical Projections of Zeit (Time) in Der Zauberberg by Thomas Mann
}

\author{
Mayté Morales, Juani Guerra \\ Instituto de Investigaciones Biomédicas y Sanitarias, Universidad de Las Palmas de Gran Canaria, Las Palmas, Spain \\ Email: mayte020472@yahoo.de
}

How to cite this paper: Morales, M., \& Guerra, J. (2021). Quantitative Study of the Metaphorical Projections of Zeit (Time) in Der Zauberberg by Thomas Mann. Open Journal of Modern Linguistics, 11, 727-745. https://doi.org/10.4236/ojml.2021.115058

Received: February 7, 2021

Accepted: September 14, 2021

Published: September 17, 2021

Copyright (๑) 2021 by author(s) and Scientific Research Publishing Inc. This work is licensed under the Creative Commons Attribution International License (CC BY 4.0).

http://creativecommons.org/licenses/by/4.0/

\section{(c) (i) Open Access}

\begin{abstract}
In this article we will analyze, in a delimited corpus of narrative production, how the notion of time is organized in complex interaction with our cognitive conceptual system. The analyzed corpus belongs to the novel Der Zauberberg by Thomas Mann, which is a masterpiece of this author. The aim is to map the metaphorical network that projects the concept TIME in Der Zauberberg. A metaphorical system refers to the network of metaphors that looms over a concept to co-create it. Different authors have studied the organization of these metaphorical systems, especially in the domain of emotions (Barcelona, 1986; Lakoff \& Kövecses, 1987). In order to bring to light the metaphorical system of Der Zauberberg, we have extracted the complete set of metaphorical expressions of TIME from the German original version of Der Zauberberg. These expressions have been located and systematized according to the conceptual metaphor to which they belong. We have been categorizing the linguistic expressions of the corpus of study, following the typology of Lakoff and Johnson (1980) and their developments. This study builds on relevant research questions and findings on how metaphorical networks work and also how they co-create a concept, which is, in this case, the concept of TIME (Zeit).
\end{abstract}

\section{Keywords}

Cognitive Linguistics, Conceptual Metaphor, Metaphor Analysis, Literature, Der Zauberberg, Thomas Mann

\section{Introduction. What Actually Occurs with the Topic of Time in Der Zauberberg}

In narrative fiction, time is organized in two ways: the time of the story that is 
narrated, and the time of the narrative. Both temporal trajectories progress in complex interaction with one another to provide the structure of the narrative with elements that singularize it with regard to other stories, trying to generate an exclusive temporality of the story. ${ }^{1}$

The first, referring to historical time, serves as a basis for understanding the concept of temporality and contextualizing the narrative. This time allows us to contextualize the piece of work in a precise historical moment, with its social and cultural characteristics that determine the conception and creation of the textual world. In Der Zauberberg this historical reference of time coincides with the First World War.

Der Zauberberg is frequently mentioned as an example of a Modernist novel in the Theory of Literature. ${ }^{2}$ Here Helmut Koopman (1983: p. 31) informs us that what is really "modern" in this novel is the philosophical reflections that Thomas Mann expresses on different prevailing topics in the historical era of the novel, among these, time. He states:

"Seine Antworten sind nicht Antworten an sich, sondern das darf man aus der Gesamtkenntnis seines Werkes und der person Thomas Manns in aller Vorsicht folgernzeitbezogene philosophische Aussagen, und so geht es nicht um eine grundsätzliche Antwort auf eine grundsätzliche Frage, sondern um eine zeitbedingte Antwort auf eine zeitbedingte Frage. Was der 'Zauberberg' mitzuteilen hat, gilt im wesentlichen für die unmittelbare Nachkriegszeit und für die Zeit der Weiremarer Republik."

"His answers are not answers in themselves, but (from) the total knowledge of his work and of the person that is Thomas Mann the philosophical statements that refer to his (historical) time should be considered; and we are therefore not talking about a fundamental answer that is given to a fundamental question, but rather it is a conditioned answer to a question also conditioned (by the era in which it lives). What 'Der Zauberberg' has to communicate to us is mainly valid for the immediate post-war time and for the age of the Weimar Republic."3

We agree with Koopman's view in the sense that surely Mann's philosophical reflections and responses can only be seen in the referential framework of the time he lived; but the reflections he makes about the nature of time in particular cannot be matched to a given time, quite the opposite, they are still a subject of study today, and in addition, his way of artfully configuring time in narratives, defined the Modernist novel.

On this matter, Thomas Mann creates a novel about time, also taking into consideration time from these two points of view: on the one hand, the time in which the story takes place, and on the other hand, the time that the characters "feel". Thomas Mann's conception of time bears a similarity to the conception of the French philosopher Bergson, who explains that abstract time is that which

${ }^{1}$ Cf. Ricoeur (1980). "Narrative Time”. Critical Inquire 7 (1): 169-190. doi: 10.1086/448093.

${ }^{2}$ Cf. Eisele Ulf (1984). Die Struktur des modernen deutschen Romans. Thübingen.

${ }^{3} \mathrm{My}$ translation. What has been added in brackets serves to add further coherence to the text. 
we use for concrete purposes, which society quantifies by clock, while "real" time cannot be measured. Let's remember that Bergson uses the concept durée to measure the duration of an event in "real" time. Only our conscience can perceive this duration, and we cannot measure it.

If we pay attention to the following example from our corpus, we will see how Joachin ${ }^{4}$ moves from "abstract" time to "real" time. A week is a long period of time, but nevertheless, he fails to measure it easily, a thermometer being the excuse to return to "abstract" time, because up in the Berghof the sick people move in a social world where abstract time is not measured, because there is no reason to do so.

“...der Zeit, dann vergeht sie sehr langsam. Ich habe das Messen, viermal am Tage, ordentlich gern, weil man doch dabei merkt, was das eigentlich ist: eine Minute oder gar ganze sieben, wo man sich hier die sieben Tage der Woche so gräßlich um die Ohren schlägt."

...time passes very slowly. I really like to take my temperature four times a day, because at that moment one truly realizes what a minute really is...or seven; while in a terrible way, the seven days of a week are ignored here. $^{5}$

This is the first time that Hans Castorp, the main character, philosophizes about the passing of time to conclude that the way of feeling it is related to the monotony of the circumstances, or, on the contrary, to the bliss of the moment that is lived. This way of feeling time is what Bergson calls durée. In time, for Bergson, the constituent elements of reality reside, which are only known from within; let us say then that the structure of Der Zauberberg depends on the durée, in other words, on how the characters feel time. We see throughout the book how the protagonist shifts from living in the "abstract" time of the Flachland to being unable to feel the flow of time, to living completely immersed in durée.

Our work is considered innovative exactly at this point. Here it is clear that this is the narrative technique that Thomas Mann, as a master of the modern and contemporary narrative, consciously uses. From Cognitive Linguistics and Cognitive Poetics, and especially diagramming the metaphorical analysis of the concept time in the novel, we intend to answer this question: "Which unconscious mechanism is used to create the illusion that time has stopped in Davos Platz, the illusion of non-time?"

\section{Theoretical Framework}

\subsection{The Textual World of Der Zauberberg}

One of the explanations that Cognitive Linguistics gives us about language is ${ }^{4}$ Character from Der Zauberberg.

${ }^{5}$ All examples in this article have been taken from Morales Santoyo and Guerra De La Torre (2015). Biopoética y lingüística cognitiva: Proyecciones metafóricas y conceptualización de “Zeit" en el texto "Der Zauberberg" (1924), de Thomas Mann. Dissertation. ULPGC. https://accedacris.ulpgc.es/bitstream/10553/17255/3/0723879_00000_0000.pdf 
that people reason not on the basis of logic, but on their experience of the world (Radden, 1992: p. 513); language, which is what makes us human beings, does not follow the laws of logic either, but is influenced by all that affects us as such human beings. Language is a utensil that helps us organize our experience in the world. As Porto-Requejo (2007: p. 12) explains:

With the acquisition of language, we also acquire an image of the world. Reality is extremely complex and we would not be able to handle such a large amount of data as we perceive on a daily basis if we did not have an effective means of organizing our knowledge about everything around us. (...) We can then deduce that, if language is the instrument by which we build reality, language will also allow us to build other alternative realities, other images of the world: the worlds of fiction. ${ }^{6}$

Therefore, the mechanisms that our cognitive system uses to understand and assimilate the reality of the world are the same ones that it uses to interpret a text. In this paper we will see how Thomas Mann builds a different world in Der Zauberberg, a world in which temporal reality differs from our daily temporal reality and its expression in ordinary German language. According to the Text World Theory, that mental image is the representation of a world; a complex and rich image; just like the one we create ourselves to understand the world around us (Werth, 1999; Gavins, 2005, 2007).

Gavins also talks about "the key elements of the world", which can be time, locality and objects. Textual "modality" is a main concept in the Theory of Textual Worlds, which tells us that a reader makes use of all his resources, linguistic or not, to understand a text, for the creation of a parallel universe in which the text is coherent. For this reason the methodological framework of Cognitive Linguistics seems to us the most suitable for our cognitive-poetic study, because of its integrative nature, since it considers language to be a whole, a continuous one, in which semantics cannot be separated from pragmatics, or linguistic capacity from the rest of human abilities.

Cognitive Linguistics uses many more tools: like metaphors, categories, cognitive models, knowledge schemes, frameworks, etc. In this study we will mainly use metaphorical analysis to map the concept of time in Zauberberg's particular "textual world". Our work is framed in Biopoetics, a new consideration of Cognitive Poetics that understands it in the more dynamicist frame of Complex System Theory (Guerra de la Torre, 2016). What we reveal here as metaphorical projections of time in Mann would thus be the foundation of the Modernist narrative complexity on which the work is based.

\subsection{Metaphorical Systems}

What is a metaphorical system? When we talk about the metaphorical system we refer to the network of metaphors that looms over a concept to co-create it.

${ }^{6}$ Our translation. 
As Lakoff and Johnson say, it is the conceptual structure, the thought structure, what gives us the meaning and the understanding, and that is exactly what they define as metaphor. They propose an imminent separation between the linguistic level and the conceptual level:

"The word 'metaphor' [...] has come to mean 'a cross-domain mapping in the conceptual system'. The term 'metaphorical expression' refers to a linguistic expression (a word, phrase or sentence) that is the surface realization of such a cross-domain mapping (this is what the word 'metaphor' referred to in the old theory)."

The TIME element in this novel, a concept that occupies a central role in the development of the story that is narrated, is presented as a concept of highest complexity; it is the subject of numerous metaphorical projections to cover it in all its dimensions. It also happens with other concepts that we consider important in our lives: we "metaphorize" them in many different ways. Therefore we will reveal different metaphors to grasp the meaning of time that Thomas Mann creates in the textual world of Der Zauberberg, each of which will enhance one aspect and obscure others, thus favoring a global understanding of the concept (Lakoff \& Turner, 1989). The network of these metaphors that builds the concept of time is what we call the metaphorical system; we illustrate this explanation with the definition of Porto-Requejo (2007), based on the initial ideas of Lakoff and Johnson (1980).

"The set of metaphorical projections that characterize a concept does not consist of a mere accumulation of metaphors, but all of them make up perfectly organized metaphorical systems, consistent with each other, but above all, consistent with the knowledge of the world that the reader possesses."

There are different authors who have studied the organization of these metaphorical systems, especially in the domain of emotions (Barcelona, 1986; Lakoff \& Kövecses, 1987; Kövecses, 1990). We have chosen Lakoff's model for our research.

Lakoff tells us about the "vertical" organization of metaphorical systems, in which lower-level projections "inherit" the structures of higher-level projections (Lakoff, 1993: p. 222). With regard to the vertical organization of metaphorical systems, according to Lakoff, metaphors take place at the most abstract level, although it is at the linguistic level, the most specific, where projections that mean something to us are given, since, as Lakoff explains, the basic level is "the level of mental images and the richest knowledge structures" (Lakoff, 1993: p. 212).

For example, TIME IS A FLUID is a basic level metaphor, which could be even more specific (TIME IS SAND, and both depend on a generic-level metaphor such as ABSTRACT ENTITIES ARE SUBSTANCES). This is illustrated in

${ }^{7}$ Lakoff (1993: p. 203).

${ }^{8}$ Cf. Porto-Requejo (2007) Poética Cognitiva: Análisis Textual de una Fantasía. Universidad de Alcalá. Servicio de Publicaciones. Alcalá de Henares. (our Translation). 
the following diagram ${ }^{9}$ (Figure 1).

As for another type of organization of metaphorical systems, in studying emotions, Kövecses ${ }^{10}$ found subcategories, generalizations and specifications; however the most relevant thing he found was the possibility of discovering new metaphor systems from the notion of "scope of metaphor". In his research he concludes that the different metaphors that make up the meaning of emotions constitute an intricate system around the generic concept of STRENGTH, so ultimately all the metaphors of emotion refer to a single master metaphor: EMOTION IS A FORCE. ${ }^{11}$

As Barcelona (2003: p. 6) explains, for the construction of a conceptual domain (like TIME in our study) the key element is the system of metaphors and metonymies, the combination of a large number of metaphors and metonymies. In our study we focus only on the network of metaphors, as a way to simplify our analysis of such an extensive corpus. Our goal in relation to the analysis of Der Zauberberg's metaphorical system will be finding the underlying metaphor in this metaphorical system, and explaining how the whole textual world of Der Zauberberg revolves around this underlying or master metaphor, as it is called by Kövecses ${ }^{12}$. In this sense Barcelona explains that the complex networks of conceptual metaphors and metonymies that are woven into language are usually the superfluous manifestation of an abstract metonymy or metaphor that hides beneath the surface ${ }^{13}$ :

Complex hierarchical networks of conceptual metaphors and metonymies have been discovered in English and other languages, which reveal that a given metaphor or metonymy is often just a particular manifestation of a more abstract superordinate metaphor or metonymy.

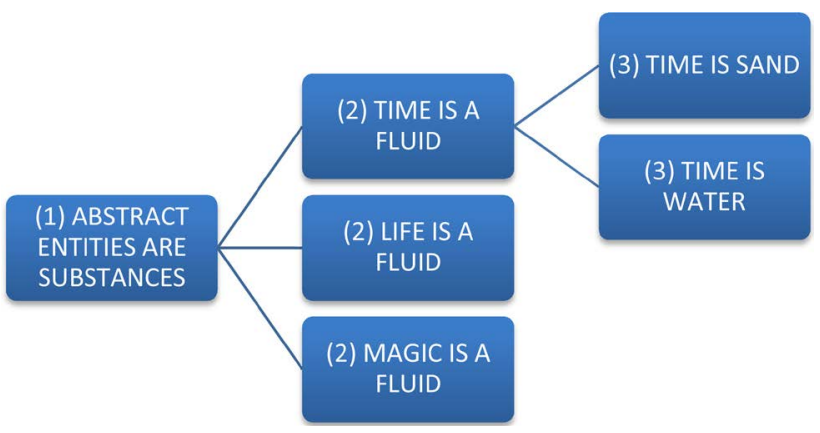

Figure 1. Hierarchical classification of metaphors $(1=$ extraordinary level; 2 = basic level; 3 = subordinate level).

\footnotetext{
${ }^{9}$ Figure 1 -Hierarchical classification of metaphors $(1=$ extraordinary level; 2 = basic level; $3=$ subordinate level). Adapted diagram of Porto-Requejo (2007: p. 75).

${ }^{10}$ Kövecses Z. (1995) “American Friendship and the Scope of Metaphor". Cognitive Linguistics 6, 4 (pp. 315-346).

${ }^{11}$ Id. (Kövecses, 2000a, 200b).

${ }^{12} \mathrm{Id}$.

${ }^{13}$ Barcelona (2003). Metaphor and Metonymy at the Crossroads. A Cognitive Perspective. Berlin/ New York: Mouton de Gruyter. p. 6.
} 


\section{Methodology: How Has the Metaphorical Analysis Been Performed}

We have selected a narrative corpus because it has been more revealing to us when it comes to delimiting specificities in the dynamics of conceptualization of time in Der Zauberberg, the original novel. It aims to provide analytical importance not only to projections that implicitly shape conceptual metaphors, but to those explicitly constructed by the writer as linguistic metaphors. It is considered to be a way of distinguishing two types of creative processes by Thomas Mann during the written elaboration of the text, the implicit and explicit. Specifically we have used the text of Mann (2009) for the analysis of the metaphorical system.

First we have extracted metaphorical expressions of TIME from the German version of Der Zauberberg. These expressions have been located and systematized according to the conceptual metaphor to which they belong. Following this outline we have been categorizing the linguistic expressions of the corpus of study, following the typology of Lakoff and Johnson (1980) and their developments.

\section{Results of the Metaphorical Analysis}

This section demonstrates the results of the metaphorical analysis of the German concept ZEIT within the methodological and theoretical framework of Cognitive Linguistics and Poetics.

\subsection{Conceptual Metaphors of Zeit (Time) in Der Zauberberg-Structural Metaphors}

Structural metaphors conceptualize an abstract and complex field of experience across a known and more concrete field. The structure of one concept will lead to the other, so that one will be explained with the terminology of the other conceptual field. ${ }^{14}$ Examples of these metaphors are the following:

A) TIME IS MONEY

Under the generic concept, TIME IS MONEY encompasses three conceptual metaphors: TIME IS MONEY, TIME IS A LIMITED RESOURCE AND TIME IS A VALUABLE COMMODITY. In the following examples of the corpus we find that time is "metaphorized" as money.

(1) “...wie Behrens auch immer sagt, und bei der letzten Generaluntersuchung hat er gesagt, ein halbes Jahr wird des wohl ziemlich sicher noch dauern."

"Ein halbes Jahr? Bist du toll?" (...) Ein halbes Jahr? Du bist schon fast ein halbes

Jahr hier! Man hat doch nicht so viel Zeit!"

(2) Um Zeit zu gewinnen, lie $\beta$ er sich die Frage wiederholen und sagte

${ }^{14}$ Cf. Lakoff, G. \& Johnson, M. (1980). Metaphors We Live By. London: The University of Chicago Press. 
dann

(3) (...) Und nun lungere ich hier herum mit dem Termometer im Mund und zähle die Schnitzer von dieser ungebildete Frau Stöhr und versäume die Zeit.

Barcelona (2003: p. 4) explains clearly, using this example TIME IS MONEY, the hypothesis of invariance (Lakoff \& Turner, 1989: pp. 82-83; Lakoff, 1990, 1993), according to which metaphorical projection cannot violate the basic structure of the target domain, thus illustrating why metaphorical projections are only partial. In the case of TIME IS MONEY, Barcelona tells us that we think and talk about time as a value that can be "spent", which is "limited", but it is not a value that can be returned (unlike money). This limitation comes from the internal structure of the target domain, TIME, which in this domain is a resource that is spent and cannot be recovered again. ${ }^{15}$

B) TIME IS A PATH

This conceptual metaphor includes metaphorical expressions, through which portions of time will be represented as roads or travel.

(4) Er würde nun binnen kurzem am Ziele sein.

(5) ...und ihn (1) auf den Wegen des Fortschrittes und der Zivilization einem immer helleren, milderen und reineren Lichte entgegenleiten.

C) LIFE IS A YEAR

We do not find any examples of this structural metaphor in the corpus studied.

D) A PORTION OF TIME IS A DAY

THREE WEEKS ARE A DAY (IN THE BERGHOF)

A MONTH IS A DAY (IN THE BERGHOF)

This conceptual metaphor projects the length of a day in the duration of a given portion of time. It is one of the most used conceptual metaphors by Thomas Mann for the configuration of the metaphorical network of NO TIME. Consequently in some passages we find that for the inhabitants of the Berghof the minimum unit of time is three weeks, and in other passages they themselves define the minimum unit as a month. Below we include the following examples:

(6) "Nun, warte nur, du kommst ja eben erst an. Drei Wochen sind freilich fast nichts

für uns hier oben, aber für dich, der du zu Besuch hier bist und überhaupt nur drei Wochen bleiben sollst, für dich ist es doch eine Menge Zeit.

(7) "O dio, drei Wochen! Haben Sie gehört, Leutman? Hat es nicht fast etwas Impertinentes, zu sagen: Ich komme auf drei Wochen hierher und reise dann wieder? Wir kennen das Wochenma $\beta$ nicht, mein Herr, wenn ich Sie

\footnotetext{
${ }^{15}$ Citing Barcelona's (2003: p. 4) explanation literally: "I give you my money and it is perfectly possibly that, if asked to do so, you will give me back exactly the same money, not only the same amount of money, but also the same the notes and coins; however, if I give you my time you cannot give me back exactly the very minutes, hours or days I spent on you; you can, however, give me back the same amount of time."
} 
belehren darf. Unsere kleinste Zeiteinheit ist der Monat.

E) OTHER STRUCTURAL METAPHORS

Other examples of structural metaphors that appear in our corpus, in which we find metaphorized time as a target domain, are the following:

TIME/LIFE IS LIGHT

(8) ...Es dämmerte rasch. Ein leichtes Abendrot, das eine Weile den gleichmäßig bedeckten Himmel belebt hatte, war schon verbliechen...

LIFE IS A BURDEN, DEATH IS A SOLUTION

(9) "Nun, dann bist du ja noch ein junger Anfänger gegen sie mit deinen fünf Monaten und wirst es noch sein, den du ein Jahr auf dem Buckel hast",...

(10) ...da $\beta$ der Gro $\beta$ vater der Interimsanpassung nun feierlich überhoben.

TIME/LIFE IS A THEATER

In the corpus analyzed, only one example of this type of structural metaphor appears:

(11) Ich meine, es sind ja junge Leute, und die Zeit spielt keine Rolle für sie, und dann sterben sie womöglich.

\subsection{Orientational Metaphors}

Human beings use orientational metaphors to understand fields of imagination that are abstract. The orientations in space like up-down, in front-behind, and central-peripheral are projected on certain abstract concepts to facilitate their understanding. Daily bodily experiences are then projected on abstract concepts, prompting the appearance of metaphorical concepts loaded with spatial orientation. The orientational metaphors in this paper will give us the key to interpreting the textual world created by Thomas Mann in Der Zauberberg, as we will explain below.

A) THE FUTURE IS IN FRONT, THE PAST IS BEHIND

A basic conceptual metaphor for the representation of other images is the concept of temporal orientation; in some languages such as German, English or Spanish THE FUTURE IS IN FRONT, THE PAST IS BEHIND US. Lakoff and Johnson (1999: p. 140) characterize this metaphor as follows: "The most basic metaphor for time has an observer at the present who is facing toward the future, with the past behind the observer. We will refer to this as the Time Orientation metaphor:

THE TIME ORIENTATION METAPHOR

The Location Of The Observer $\Rightarrow$ The Present,

The Space In Front Of The Observer $\Rightarrow$ The Future,

The Space Behind The Observer $\Rightarrow$ The Past.

Examples from the Corpus are: 
(12) Es schneite den ganzen Nachmittag fort... Am nächsten Morgen schneite is nicht mehr; ...

(13) Und so war denn Zufriedenheit in Hans Castorps Herzen darüber, da $\beta$ zwei leere und sichere gefriedete Stunden vor ihm lagen.

\section{B) PROXIMITY IN SPACE IS PROXIMITY IN TIME}

This conceptual metaphor permeates the TIME phenomenon of spatial orientation. Here the focus is on the projection of the antonyms central-peripheral, according to which an event that is expected in the future will be conceptualized spatially as distant. On the contrary, an event close to the present will be conceptualized as spatially close. This is visible in the corpus we are studying:

(14) Noch gestern war er völlig in dem gewohnten Gedankenkreise befangen gewesen, hatte sich mit dem jüngst Zurückliegenden, seinem Examen, und dem unmittelbar Bevorstehenden seinem Eintritt in die Praxis bei Tunder \& Wilms...

(15) Man wollte wissen, da $\beta$ sie schon als ganz junges Mädchen in Lungensanatorien eingetreten sei und seitdem nicht mehr in der Welt gelebt habe.

\section{C) UP IS GOOD, DOWN IS BAD}

Lakoff and Johnson (1980) talk about the epistemology and ontology that give rise to the orientation metaphors, explaining that these spatial orientations are based on the nature of the human body. The human body rises erect, overcoming the force of gravity, from there arise the connotations of "ERECT/UP IS GOOD".

The conceptual metaphor UP IS GOOD, DOWN IS BAD is based on the personal and physical experience of feeling good within your body. Luck, health, life and other parts that involve a positive experiential feeling are normally conceptualized as "upward-facing". This orientation also appears in other conceptual metaphors that are subcategories of the former, such as BEING HAPPY IS UP, HEALTH IS UP and LIFE IS UP.

Certain linguists consider the linguistic realizations of this conceptual metaphor as metonymies (Barcelona, 2003: p. 9).

This particular orientation metaphor is key to the cognitive interpretation of the novel Der Zauberberg, we will scrutinize how the main conceptualization is organized the opposite way in the textual universe of Der Zauberberg. Thomas Mann conceptualizes UP IS BAD, DOWN IS GOOD, with which, as we illustrate in the examples, those subcategories that derive from this conceptual metaphor, are radically modified, as TO BE ABOVE IS TO BE DEAD, DISEASE IS UP, SADNESS AND DESPAIR IS UP; these conceptual structures (des) organize the metaphorical network of temporal cognition, prompting a new narrative self-organizing cognitive, affective and axiological meaning.

Examples:

(16) (...) Und nun lungere ich hier herum mit dem Termometer im 
Mund und zähle die Schnitzer von dieser ungebildete Frau Stöhr und versäume die Zeit.

(17) Manchmal nimmt sie sich besser aus, besonders im Schnee. Aber man sieht sich sehr satt an ihr. Wir alle hier oben, kannst du mir glauben, haben sie ganz unaussprechlic sat,...

(18) Es war so phosphoreszierend bleich wie Dr. Krokowski, und vorneauf sa $\beta$ der Herrenreiter, der sehr unbestimmt aussah, wie jemand, den man lediglich hat husten hören, und lenkte. "Das ist uns doch ganz einerlei, und hier oben", sagte der verrenkte Joachin,...

As a global narrative level of meaning evolution and the way all other concepts make sense and are particularly entrenched, it is one of the most interesting metaphors in that it reverses the regular pattern in the general metaphor TIME IS SPACE, which is as abundant in everyday German. This supports the new type of literary text as experimental and Modernist.

(19) Zwei Reisetage entfernen den Menschen vund gar den jungen, im Leben noch wenig fest wurzelnden Menschen iseiner Alltagswelt, all dem was er seine Pflichten, Interessen, Sorgen, Aussichten nannte, viel mehr, als er sich auf der Droschkenfahrt zum Bahnhof wohl träumen lie $\beta$.

\subsection{Ontological Metaphors and Personification}

This group of metaphors gives rise to linguistic and metaphorical expressions that conceptualize abstract concepts making them concrete through objects and substances that can be seen, smelled or touched. A special case of ontological metaphors is personification, by which an abstraction of a certain scope can be conceptualized in order to make sense through a human example.

A) TIME IS MOVEMENT

Our daily understanding of time is structured on a model in which time moves from the perspective of the speaker; it is then conceptualized as an object. The direction of the movement will be from front to back. This understanding of time is most often manifested and described in the literature of the languages studied so far. ${ }^{16}$

The conceptual metaphor TIME IS MOVEMENT consists of two subordinate concepts, TIME IS AN OBJECT THAT MOVES AND TIME IS STILL AND WE MOVE THROUGH IT.

A.1) TIME IS A MOVING OBJECT is a metaphor which Lakoff and Johnson (1980: pp. 42-44) call THE MOVING TIME METAPHOR (Lakoff \& Johnson, 1999: p. 141). In this model time moves from the future to the past, moving through the speaker. Human beings are understood as the center of events. This metaphor corresponds in German and Spanish to our human perception in which we experience the future as something new, the present as the here and now and

${ }^{16}$ See Lakoff (1990: pp. 55-57), Lakoff and Johnson (1980: Kap. 9), Lakoff and Johnson (1999, p. 141147), Radden (1997: pp. 438-444). An atypical case is the study of R. Nunez with the Aymara. 
the past we leave behind us (Radden, 1997). This is not so in other languages as observed by Sinha (2007), Núñez and Cornejo (2012), etc.

(20) öffentlichen Sinne gesprochen, so war die Zeit über Hans Lorenz Castorps Wesen und Willensmeinungen schon lange vor seinem Abscheiden hinweggegangen.

(21) ..., die im Gange der Zeit des Stückes Inhaber gewesen: Es waren ihrer schon sieben,

\section{A.2) TIME IS STILL AND WE MOVE THROUGH IT.}

In this conceptual metaphor the observer moves as he observes time as a motionless object. Lakoff and Johnson describe this model as TIME IS STATIONARY AND WE MOVE THROUGH IT (Lakoff \& Johnson, 1980: pp. 43-44) or THE MOVING OBSERVER METAPHOR OR TIME'S LANDSCAPE (Lakoff \& Johnson, 1999: pp. 145-146). In this model time as movement goes from the past to the future, but time is a static reference point. The following metaphorical examples specify the type of movement in Der Zauberberg. The speaker "passes" through time:

(22) Ich komme auf drei Wochen hierher und reise dann wieder? Wir kennen das Wochenma $\beta$ nicht, mein Herr, wenn ich Sie belehren darf.

(23) Als sie vom Essen wieder heraufkamen, lag das Paket mit den Decken schon in Hans Castorps Zimmer auf einem Stuhl, und zum erstenmal machte er an dies an Tag Gebrauch davon,

\section{A.3) TIME IS CYCLICAL}

These structures show regular repetitions of a time structure. These frequent occurrences are based on the natural phenomena that we observe daily: the day ends, night comes; summer is followed by winter, the rotation of the earth. The repetition of natural phenomena allows us to measure time. Life involves cycles that are repeated and repeated continuously. As we have already said, Thomas Mann preferably conceptualizes time as cyclical in this novel, so we come across countless examples throughout the novel:

(24) Abermals sa $\beta$ er an seinem Platze im Saal mit dem einfältig bunten Gewölbe, den sieben Tischen, izum viertenmal. Etwas später, um sieben Uhr, sa $\beta$ er zum fünftenmal dort,...

(25) eines zugleich Ziehenden und Stehenden, eines wechselnden Bleibens, das Wiederkehr und schwindelige Einerleiheit war, veine Empfindung, die ihm von früheren Gelegenheiten her bekannt war, und von der wieder berührt zu warden ererwartet und gewünscht hatte: sie war es zum Teil, um derentwillen ihm die Vorzeigung des stehend wandernden Erbstücks angelegen gewesen war.

(26) 1. "Nun sind es bald acht Jahre", sagte er, "da $\beta$ wir dich darüber hielten und da $\beta$ das Wasser, mit den du getaufst wurdest, da hinein floß.....)" 
2. Und vierundvierzig Jahre sind es in den nächsten Tagen, da war dein seliger Vater der Täufling,(...)

3. Aber vor fünfundsiebenzig Jahren, da war ich selber, den sie tauften, $(. .$.

B) TIME IS A SUBSTANCE

In this type of conceptual metaphor, we find the phenomenon of conceptualized time to be a substance or object. Here you will find characteristics such as weight, limits, taste, smell, quantity or dimension of an object. In the following linguistic accomplishments we see how time can be "carried" or considered as a beautiful object that we "enjoy".

(27) Sie war wohl anderthalb Jahre hier...

(28) Will's Gott, so wird es noch schöne Sommertage geben. Selbst im September ist das noch sehr wohl möglich.

As time is here conceptualized as an object, it can also be portioned into parts, which will be more or less important, depending on the function they perform, as we can see in the following example:

(29) nach dem Essen war Liegekur bis zum Tee, isogar die wichtigste des Tages und streng einzuhalten.

C) TIME IS DISTANCE

This conceptual metaphor TIME IS DISTANCE may seem like that of TIME IS A PATH. But while TIME IS A PATH is framed within the structural metaphors, and the linguistic metaphors we find have more to do with the structure of a path, the stumbles that we can encounter along it and the beginning or end of a path. TIME IS DISTANCE is an ontological metaphor, in which the measurement characteristic of a distance prevails. The geometric-spatial concept of "distance" is further prioritized.

(30) Von Hamburg bis dort hinauf, das ist aber eine weite Reise; zu weit eigentlich.

(31) "Ist jetzt euer Sommer zu Ende?" “-fragte Hans Castorp am dritten Tage ironisch seinen Vetter..."

(32) "Komisch ist und bleibt es, wie die Zeit einem lang wird zu Anfang, an einem fremden Ort. Das heißt..."

D) TIME PORTIONS ARE CONTAINERS

Here the abstract phenomenon of time will be defined by specific limits, as well as with an interior and an exterior.

(33) Der zweite Tag, den Hospitant vollständig hier oben verlebt hatte, war prächtig sommerlich gewesen.

Similarly, a piece of time can be full or empty:

(34) Es schneite den ganzen Nachmittag fort. 
A special case of THE CONTAINER METAPHOR is the concept EXISTENCE IS PRESENCE WITHIN A CONTAINER. Here the human being is structured as a presence within a container or a delimited space, as in the following examples:

(35) Die Damen waren schon zum ersten Frühstück im zarten Waschblusen erschienen,

(36) Sie blieb eine gute Weile im Wasser, um dies oder jenes zu bekommen.

In the next example it is nature that irrationally "appears" or "emerges" within a time container:

(37) Am dritten Tage jedoch war es genau, als ob die Natur zu Falle gebracht und jede Ordnung auf den Kopf gestellt würde;...

\section{E) PERSONIFICATIONS}

Lakoff and Johnson identify the basic concept of EVENTS ARE ACTIONS as the center of the personification process. The source domain (ACTIONS) is a subcategory of the target domain (EVENTS). The opposite could not happen: Not every event is an action. Such conceptual metaphors can personify events such as death or time, as Martín Dueñas and Guerra de la Torre (2014) has shown in his study of T.S. Eliot's The Waste Land in English, Marta Silvera in her thesis on Thomas Pynchon ${ }^{17}$. Since events have a beginning and an end, time can be "segmented", so we can measure time, due to the fact that the repetition of events is measurable. (Lakoff \& Johnson, 1999: 138)

(38) (...), als ihm ganz unverhofft die ausgezeichnete Einsicht zuteil wurde, was eigentlich die Zeit sei: nämlich nicht anderes, als einfach eine Stumme Schwester, eine Quecksilbersäule ganz ohne Bezifferung, für diejenigen, welche mogeln wollte,...

(39) “Der Ärmste!" sagte sie. "Der pfeift bald aus dem letzten Loch. Schon wieder mu $\beta$ er sich mit dem Blauen Heinrich besprechen."

\subsection{Creative Metaphors}

Cognitive linguists emphasize that all conceptual, conventional, and creative metaphors follow the same mechanisms and the same principle of invariance ${ }^{18}$. How do we know it is a creative metaphor? The conventionalization of a metaphor lies in polysemy, which refers to the fact that a word has two meanings (Kurz, 1997: p. 17), and the reader deems "a meaning that is dominant and outgoing". Polysemy then points us to a meaning that deviates from the standard,

\footnotetext{
${ }^{17}$ Martín Dueñas and Guerra de la Torre (2014) Cognitive dynamics of the poetic and linguistic complexity of the concept "TIME". Conceptual modeling in T.S. Eliot's text "The Waste Land" (1922). PhD Dissertation. ULPGC. http://hdl.handle.net/10553/12202; Silvera Roig and Guerra De La Torre (2016) Biopoetics, cognition and emotion: conceptual integration and emergence in Thomas Pynchon's The crying of Lot 4. PhD Dissertation. ULPGC. http://hdl.handle.net/10553/18017.
} 
which is not known to either the reader or the listener; that is, they are metaphors that "surprise" the reader, these metaphors evoke unusual aspects of what is normally conceptualized, hence their originality. One of the most unusual examples of creative metaphors in the novel is when Mann conceptualizes TIME IS A MEDICINE; it appears constantly in the novel when the sick speak of the period of time prescribed to them by Dr. Behrens; usually prescribed every six months.

(40) "Ja, da sitzen wir nun und lachen", sagte er mit schmerzendem Gesicht umzuweilen... und dabei ist gar nicht abzusehen, wann ich hier wegkomme, denn wenn Behrens sagt: noch ein halbes Jahr, dann ist es knapp gerechnet, man mu $\beta$ sich auf mehr gefa $\beta t$ machen.

\section{Statistical Results and Conclusions}

\section{Statistical Analysis of the Linguistic Corpus Studied from Der Zauberberg}

The following diagram (Figure 2) shows the provenance of the linguistic metaphors studied in relation to the conceptual metaphor from which they come and we will draw the conclusions below it.

1) As we can observe in the diagram (C), in the analyzed corpus of Der Zauberberg, we clearly see that all metaphorical expressions describing time are based on conceptual metaphors. As we can see in the previous diagram all the metaphors studied refer to a particular conceptual metaphor, including those metaphors we have considered to be "creative metaphors". So the metaphor is not merely word play or ornaments for daily speech. Our relationship to the world and basic cognitive processes underlying the production of meaning are essentially metaphoric (Lakoff \& Johnson, 1980).

\section{ANALYSIS OF METAPHORICAL STRUCTURES ACCORDING TO THEIR ORIGIN}

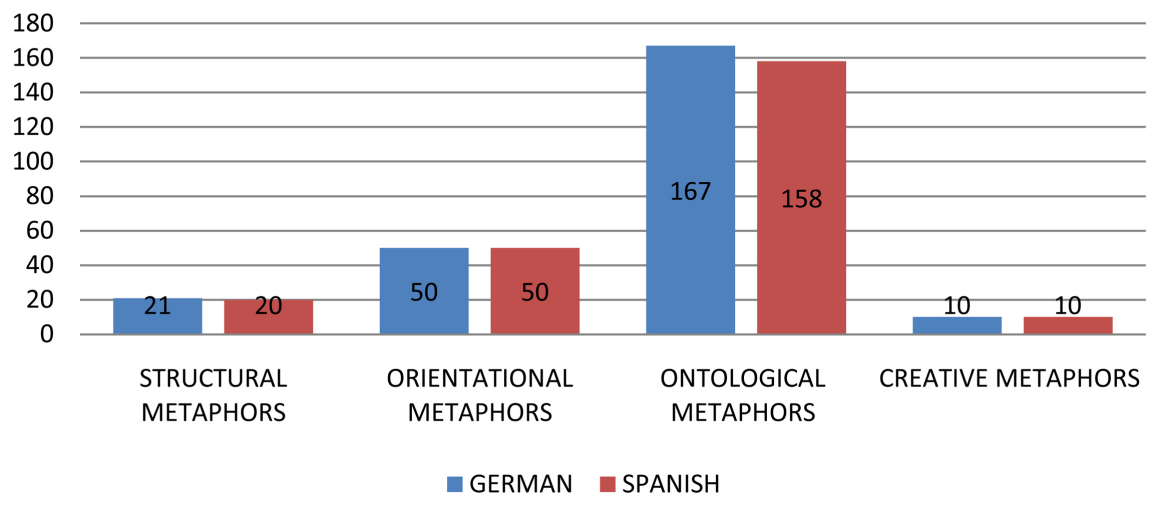

Figure 2. Overview of the conceptual metaphors of the corpus studied. ${ }^{19}$

\footnotetext{
${ }^{19}$ Figure 2-The corpus studied in our thesis was both from the original novel in German, as well as from the Spanish translation, as the thesis was written in Spanish, this allowed us a further comparative perspective of the conceptual metaphors in both languages which will be published in a separate article. (See references in Bibliography).
} 
2) In the corpus studied, we see that several conceptual metaphors usually appear at once in the study of a text fragment. Let us focus on a randomly chosen example:

Denn es war ja nun (1) schon das drittemal binnen (2) so kurzer Zeit und bei so jungen Jahren, da $\beta$ (3) der Tod auf den Geist und die Sinnenamentlich auch auf die Sinne-des kleinen Hans Castorp wirkte;(...) (4) In den drei oder vier Monaten, seit sein Vater gestorben war, (5) hatte er den Tod vergessen; nun erinnerte er sich, und alle Eindrücke von damals stellten sich genau, gleichzeitig und duchdringend in ihrer unvergleichbaren Eigentümlichkeit wieder her.

(1) TIME IS AN OBJECT,

(2) TIME IS DISTANCE AND TIME PERSONIFICATION,

(3) PERSONIFICATION: DEATH IS A FORCE,

(4) TIME PORTIONS ARE CONTAINERS,

(5) CREATIVE METAPHOR/DEATH IS AN OBJECT/DEATH IS A THOUGHT.

We can count at least five conceptual metaphors in a single paragraph, because as we have already mentioned in this paper, TIME in this Modernist novel is such a complex concept that it cannot be conceptualized with a single metaphor; our metaphorical analysis emphasizes that the network of metaphors which co-create the concept responds to an enhanced biopoetic experience of time in the frame of what Bergson called durée. Narrativity and temporality are complexly related thus injecting more creative dynamicism to the communicative system, and as closely integrated as Ricoeur thought while investigating the topic of narrative time ${ }^{20}$.

3) The structural conceptual metaphors found in the corpus form only $8.8 \%$ of the total metaphors studied. Of the following structural metaphors we find no examples in the corpus. This is consistent with the poetic dynamics of complexity of an avant-garde literary text (Guerra de la Torre, 1992, 2013).

DEATH IS THE END OF THE ROAD

LIFE IS A YEAR, TO SLEEP IS DEATH

LIFE IS A RIVER

4) The most important conceptual metaphors in der Zauberberg.

As we can see in the diagram (Figure 3), within the ontological conceptual metaphors, after the SUBSTANCE METAPHORS, the most proliferating metaphors in the text are TIME IS MOVEMENT and THE ORIENTATIONAL METAPHOR which leads to the reconsideration that the elements such as time and space are inextricably tied with narrative, both in the sense that it cannot be conceived outside its expression in narrative (Ricoeur, 1984) ${ }^{21}$. We can conclude as Herman ${ }^{22}$, that spatial reference plays a "crucial, not an optional or derivative,

${ }^{20}$ cf. Ricoeur, P. (1984) Time and Narrative. Trad. Kathleen Mclaughlin y David Pellaur. Chicago. ${ }^{21} \mathrm{Id}$.

${ }^{22}$ Cf. Herman, D. Story logic. Problems and possibilities of narrative. Lincoln, NE: University of Nebraska Press. 
CONCEPTUAL METAPHORS IN DER ZAUBERBERG

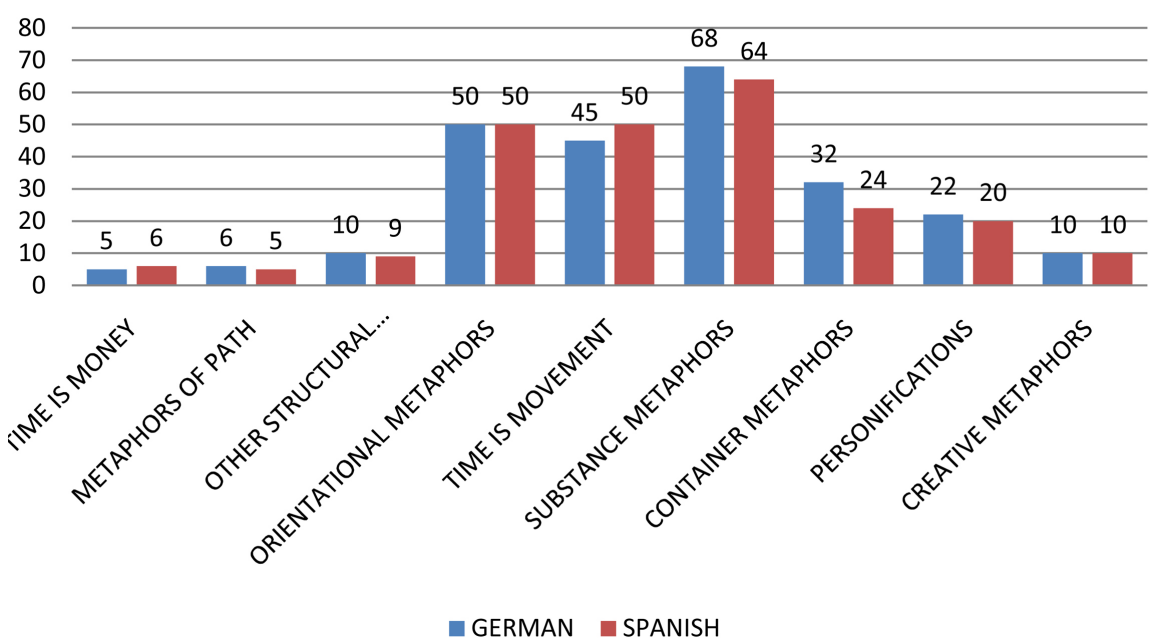

Figure 3. Conceptual metaphors in Der Zauberberg.

role in stories since narrators propose interpretations of actions and characters through the spatial organization of the plot as much as through its temporal mapping. In the same perspective, scholars ${ }^{23}$, like Adams, have also questioned the "belief that temporality is the only significant dimension" in narrative and have started to consider with greater interest the role of other dimensions such as space and their interplay with time to structure story-worlds and the events in them.

In our analysis SUBSTANCE METAPHOR has revealed as the most important ontological metaphor, what supports the theory of Lakoff and Johnson, which says "that they are generally taken as straightforward and obvious descriptions of mental phenomena." In fact, they say, ontological metaphors are among the most basic devices we have for understanding our experience.

5) The metaphors that we have distinguished as creative account for $4 \%$ of the total corpus, let us look at some examples to corroborate what has already been widely studied from Cognitive Linguistics, that creative metaphors have the same cognitive bases as all others, and that they are formed from common cognitive metaphors. So we get to the same conclusion as most of cognitive linguists when they emphasize that all conceptual, conventional, and creative metaphors follow the same mechanisms and the same principle of invariance.

6) In this novel, the author, Thomas Mann goes further and is more radical bringing to light those experiences where time as such is themed, something that cannot be done unless he introduces the phenomenology of time-consciousness. As a general conclusion to this article, we can highlight that metaphorical analysis has been a very powerful tool to analyze the concept of ZEIT in the novel, as well as the metaphorical network that shapes this concept, since it is through metaphorical expressions that we are provided with the meaning of TIME and that

${ }^{23}$ Reviewing early work by Greimas on spatiotemporal representation in narrative (1988) and by Bakhtin on chronotopes (1981). 
we manage to interpret the imaginary textual world that Thomas Mann constructs in Der Zauberberg.

\section{Conflicts of Interest}

The authors declare no conflicts of interest regarding the publication of this paper.

\section{References}

Barcelona, A. (1986). On the Concept of Depression in American Englisch: A Cognitive Approach. Revista Canaria de Estudios Ingleses, 12, 7-33.

Barcelona, A. (2003). Metaphor and Metonymy at the Crossroads. A Cognitive Perspective. Walter de Gruyter. https://doi.org/10.1515/9783110894677

Eisele, U. (1984). Die Struktur des modernen deutschen Romans. Thübingen. https://doi.org/10.1515/9783111464718

Gavins, J. (2005). Text World Theory in Literary Practice. In H. Veivo, B. Pettersson, \& M. Polvinen (Eds.), Cognition and Literary Interpretation in Practice (pp. 89-104). Yliopistopaino.

Gavins, J. (2007). Text World Theory: An Introduction. Edinburgh University Press. https://doi.org/10.3366/edinburgh/9780748622993.001.0001

Guerra de la Torre, J. T. (1992). La naturaleza creativa del tiempo en el nuevo paradigma del caos. una relectura de T. S. Eliot. Universidad Complutense de Madrid.

Guerra de la Torre, J. T. (2013). Poética Cognitiva. (Con)figurándonos lo real. In M. L. Calero, \& M. A. Hermosilla (Eds.), Lenguaje, Literatura y Cognición (pp. 253-271). Córdoba. S.P.U.C.

Guerra de la Torre, J. T. (2016). Nueva Poética para una transversalidad realista. Revista de Occidente, 32-44.

Koopman, H. (1983). Der klassisch-moderne Roman in Deutschland. Arbitrium, 2. https://doi.org/10.1515/arb-1984-0179

Kövecses, Z. (1990). Emotion Concepts. Springer Verlag New York Inc. https://doi.org/10.1007/978-1-4612-3312-1

Kövecses, Z. (1995). American Friendship and the Scope of Metaphor. Cognitive Linguistics, 6, 315-346. https://doi.org/10.1515/cogl.1995.6.4.315

Kövecses, Z. (2000a). Metaphor and Emotion Language. Culture and Body in Human Feeling. Cambridge University Press.

Kövecses, Z. (2000b). The Scope of Metaphor. In A. Barcelona (Ed.), Metaphor and Metonymy at the Crossroads (pp. 79-92). Mounton de Gruyter. https://doi.org/10.1515/9783110894677.79

Kovecses, Z. (2002). Metaphor: A Practical Introduction. Oxford University Press.

Kurz, G. (1997). Metapher, Allegorie, Symbol. Vandenhoeck \& Ruprecht.

Lakoff, G. (1990). The Invariance Hypothesis: Is Abstract Reason Based on Image-Schemas (pp. 39-74)? De Gruyter Mouton. https://doi.org/10.1515/cogl.1990.1.1.39

Lakoff, G. (1993). The Contemporary Theory of Metaphor. In Ontony (Ed.), Metaphor and Thought (pp. 202-251). Cambridge University Press. https://doi.org/10.1017/CBO9781139173865.013

Lakoff, G., \& Johnson, M. (1980). Metaphors We Live By. The University of Chicago Press. 
Lakoff, G., \& Johnson, M. (1999). Philosophy in the Flesh. Basic Books.

Lakoff, G., \& Turner, M. (1989). More than Cool Reason. A Field Guide to Poetic Language. The University of Chicago Press. https://doi.org/10.7208/chicago/9780226470986.001.0001

Lakoff, G., \& Kövecses, Z. (1987). The Cognitive Model of Anger Inherent in American English. In D. Holland, \& N. Quinn (Eds.), Cultural Models in Language and Thought (pp. 195-221). Cambridge University Press. https://doi.org/10.1017/CBO9780511607660.009

Mann, T. (2009). Der Zauberberg. Fischer Verlag.

Martín Dueñas, A., \& Guerra de la Torre, J. T. (2014). Cognitive Dynamics of the Poetic and Linguistic Complexity of the Concept "TIME". Conceptual Modeling in T.S. Eliot's text "The Waste Land" (1922). Scientific Document PhD Thesis, Universidad de Las Palmas de Gran Canaria. http://hdl.handle.net/10553/12202

Morales Santoyo, M., \& Guerra De La Torre, J. T. (2015). Biopoética y lingüística cognitiva: Proyecciones metafóricas y conceptualización de "Zeit" en el texto "Der Zauberberg" (1924), de Thomas Mann. Scientific Document PhD Thesis, Universidad de Las Palmas de Gran Canaria. http://hdl.handle.net/10553/17255

Núñez, R., \& Cornejo, C. (2012). Facing the Sunrise: Cultural Worldview Underlying Intrinsic-Based Encoding of Absolute Frames of Reference in Aymara. Cognitive Science, 3, 1-27. https://doi.org/10.1111/j.1551-6709.2012.01237.x

Porto-Requejo (2007). Poética Cognitiva: Análisis Textual de una Fantasía. Universidad de Alcalá.

Radden, G. (1992). The Cognitive Approach to Natural Language. In M. Pütz (Ed.), Thirty Years of Linguistic Evolution: Studies in Honour of René Dirven on the Occasion of His 60th Birthday (pp. 514-541). John BenJaminsPublishing Company. https://doi.org/10.1075/z.61.39rad

Radden, G. (1997). Metaphorisierte Zeit (pp. 427-442). Dürscheid/Ramers/Schwarz.

Ricoeur, P. (1980). Narrative Time. Critical Inquire, 7, 169-190. https://doi.org/10.1086/448093

Ricoeur, P. (1984). Time and Narrative (pp. 85, 88). Kathleen Mclaughlin y David Pellauer. https://doi.org/10.7208/chicago/9780226713519.001.0001

Silvera Roig, M., \& Guerra de la Torre, J. T. (2016). Biopoetics, Cognition and Emotion: Conceptual Integration and Emergence in Thomas Pynchon's The Crying of Lot 4. Scientific Document PhD Thesis, Universidad de Las Palmas de Gran Canaria. http://hdl.handle.net/10553/18017

Sinha, C. (2007). Cognitive Linguistics, Psychology and Cognitive Science. In D. Geeraerts, \& H. Cuyckens (Eds.), Handbook of Cognitive Linguistics (pp. 1266-1294). Oxford University Press.

Werth, P. (1999). Text Worlds. Representing Conceptual Space in Discourse. Longman. 